\title{
Sorption and desorption of napropamide in sandy soil amended with chicken dung and palm oil mill effluent
}

\begin{abstract}
Beach Ridges Interspersed with Swales (BRIS) is a sandy soil and in Malaysia it is found exclusively in the east coast of Peninsular Malaysia. It is a marginal soil because of its low nutrient and water-holding capacity. However, with proper management and organic matter amendments some areas with BRIS soil are cultivated. Napropamide is a selective herbicide widely used to control weeds in BRIS soil. No previous studies have been reported on the effects of organic matter amendments on napropamide sorption in BRIS soil. This study was conducted to determine sorption and desorption of napropamide in BRIS soil amended with chicken dung (CD) and palm oil mill effluent (POME) at 0, 20, 40, and $80 \mathrm{Mg}$ hai 1. Potential interaction of dissolved organic carbon (DOC) with napropamide and their competition for sorption sites were also determined. Sorption isotherm data were fitted to the log-transformed Freundlich's equation. Sorption of napropamide was higher in soils amended with $\mathrm{CD}$ and POME as compared to non-amended soil. At the same rates of application, sorption was higher in soil amended with CD than POME. The Freundlich's coefficient (Kf) values were $0.22,3.96$, and 41.6 for nonamended soil, soil amended with $80 \mathrm{Mg}$ haī 1 POME, and soil amended with $80 \mathrm{Mg}$ haī $1 \mathrm{CD}$, respectively. Desorption of napropamide showed positive hysteresis and the hysteresis were greater with higher rates of CD and POME. There was no association between napropamide and DOC extracted from BRIS soil amended with either CD or POME and also there were no competitions between napropamide and DOC extracted from either CD or POME for sorption sites of the soil samples.
\end{abstract}

Keyword: Sorption; Desorption; Napropamide; Sandy soil; Dissolved organic carbon 